\title{
The Importance of Music in the Cultural Policy of Nigeria: A Focus on Selected Igbo Folk Songs
}

\author{
Dr. Sunday N. Nnamani
}

Music Unit, Department of Fine and Applied Arts/Music, Faculty of Humanities, Federal University NDUFU-Alike Ikwo, PMB 1010 Abakaliki, Ebonyi state, Nigeria.

sundaynnamani2010@yahoo.com

\begin{abstract}
Cultural policy is generally regarded as an instrument of promotion of National identity and Nigerian unity. It is also a means of communication and co-operation among different Nigerian or African cultures. Generally speaking, the cultural life in Nigeria is to a large extent marked by tradition and traditional forms of cultural events which are very popular. These include festivals, exhibitions, and performances, playing of music and dancing in the open. Studies in Igbo oral performance include folksongs, folksongs, riddles proverbs, histories, legends, myths, drama, oratory and festivals. These are veritable instruments of education for the younger generations into adulthood. The paper treated in details, five Igbo songs taking into consideration the language translations of the themes through content analysis of surface and philosophical meanings.
\end{abstract}

The analysed folktunes are Egwu nwa (maternity songs), Egwu echichi (installation song), Egwu akwamozu (funeral song), Egwu agha (war song) and Egwu onwa (moon-light song). Through these folksongs, the younger generation is educated morally, intellectually, socially and in creativity. Music is most sovereign more than anything else because rhythm and harmony find their ways to the innermost soul and take strongest hold upon it.

Keywords-cultural policy, folksongs, traditions and language.

\section{INTRODUCTION}

Music culture is a way of life in a country, towns and in rural communities. It is also the attitudes, feelings, thinking and beliefs of the people towards their music. This culture influences their behavioural patterns and by extension their political orientations. One of the greatest mistakes that our former nation builders made was that they saw the cultural activity of a particular society as having no relevance to the political considerations of that society.

Cultural activities especially in a nation like Nigeria with diverse ethnic groups are bound to be different. But there must be a way of forcing unity down the throats of these diverse groups as a way of convincing the Nigerian body politics that there is truly unity in diversity. Music definitely has some solutions to these problems.

\section{Definition of Terms}

Encyclopedia American International (1995) defined music as "the art by which a composer, through a performer as intermediary, communicates to a listener certain ideas, feelings or states of the mind". Hornby (2000) on its part defined music as the arrangement of sounds in a pleasing sequence or communication to be sung or played on instruments". The language of music however is not so straight forward as the language of some other disciplines. Besides expressing purely musical thoughts, it is also able to suggest definite emotions. With a little help from words or drama, it can be made to paint pictures and emotions but it is capable of awakening the emotions that had been aroused through music. Therefore, Luther in Glennon (1980) had this to say, "Music drives away the devil and makes people happy, it induces one to forget all wrath, unchastity, arrogance and other vices. After theology, I accord music the highest place and greatest honour".

Music has played an important role in the activities of all people. It further explained that music functions at several cultural levels ranging from simple and direct folk utterances such as children's games to high rituals. It plays a significant role in all societies, and exists in a historical era. A proper consideration of music should involve the musical sound itself, but should also deal with the concepts leading to its existence with its particular forms and functions in each culture and with the human behavior that is producing the sound.

More importantly too, the music of a particular society is by nature dynamic expressing the changed, changing and yet the changeable environment. The physical, natural, social and other environments in Nigeria are literally been diffused with its music. Music in the Nigerian society is 
largely functional and has close relationship with the worship of deities, ceremonies and for relaxation. In Nigeria for example, three classes of music exist, namely; the traditional or folk, popular and art or classical (Okafor, 2004a).

\section{The Concept of Music}

One may actually express that there is no particular universally accepted definition of music but many schools of thought which include musicians, philosophers and scientists have thought of music from different perspectives. For instance Okpala and Anuforom (1988) had defined music as "a universal language because it has no language or age barrier. Everybody whether young or old understands, plays, enjoys and appreciates good music.

Likewise people sing and play music written in other languages such as French, Latin, Portuguese, Hausa, Yoruba, and Igbo etc. In another perspective, music may be defined as a sacred art". We actually employ music in places of worship. The above are by no means exhaustive but we can also explain it as a social process. However, Okpala (1996) in her own ideas posited that:

Music is a social process by which human beings relate to one another through transmission of information, ideas, emotions, thoughts, norms, concepts and feelings among themselves. Music is the centre piece of life which gives human life a meaning and makes his existence worth its value. Being the heart of life, music functions like the centre of life in man. Music determines man's interactional achievements and all that becomes of it, and also dictates the tune of life as well as characterize the pattern of life and extent of development in any society. It is music that defines an individual group, people and society in general. It is always present in man (from cradle to grave) being omnipresent and ubiquitous. It permeates all human conditions. This means that it is only through music (as a process of socialization), that human beings relate to themselves, interact with one another, share from one another's problems and enjoyment; and organize their environment to make it conducive to living (page 105)

\section{Folk Music}

Nigerian music can be broadly classified into three namely; Art or academic, Folk or traditional and popular. The oldest and the most widespread is the folk music with its associated dances.

In Igbo traditional setup, folktales called (akuko ifo/iro) are sung side by side folksongs for moral or social education of the young. Folktales or story telling is an ancient Igbo human art and is usually punctuated with music and song which is filled with word-content, literature-content and other issues that matter. Their music is generally simple but the message contained in the words are deep and profound. They stimulate the imagination of the hearers, tasks their thinking faculty and are filled with philosophical meanings. They play significant roles in Igbo traditional society since through them both young and old are taught good morals, accepted norms and good behavior. (Okafor 1989, Okafor and $\mathrm{Ng}$ 'andu, 2003).

The moral songs which form the basis of these instructions on right and wrongs in human conduct, may be directed to the younger generation, but it is the commonly expressing its rules of do's and don'ts and the levels of acceptable behavior that passes its verdict. As a result of this, children's rhymes, songs and tales often share the same characteristics and contents with the art forms for the adults. They are told and performed at moonlight nights and the arena is usually the village squares. Many of these traditional stories are about animals and birds and the hero of the animal kingdom been the clever tortoise. Elders had always exhibited their level of intelligence in telling these stories which have philosophical meanings filled with fiction.

Confirming this, Basden,(1966) said,

The Ibos, have a great fondness for fairy tales. They have a big stock of legends and folklore.... The Ibo is a good story- teller, with a faculty of putting reality into fables. He uses as illustrations, animals and birds in such a way that they seem to be endowed with human powers.

Their music is strictly in short call and response/refrain form and is unaccompanied. Many definitions have been put forward by many professionals but a provisional definition of folk music is the one adopted by the International Folk Music Council in 1955 which runs as follows:

Folk music is music that has been submitted to the process of oral transmission. It is the product of evolution and is dependent on the circumstances of continuity, variation and selection...it can also be applied to music which has originated with an individual composer and has subsequently been absorbed into the unwritten, living tradition of a community...it is the fashioning and re-fashioning of the music of the community that gives it folk character (in Schole, 1970:366). 
A community's folk music is part of its memory, its life, evolution and history and because it is integral with the continuous existence of that community. Change is part of life and because of that, a community re-shapes or remodels its folk music in line with the changing environment, ideas and social interactions. It is this change that enables it fit into the changing times while its origin, history and very nature stirs the emotions of a community's historical evolution its continuity of being (Cappalletti, 1972).

The basic roots of music which include rhythm, pitch, tone, quality and intensity are found in the music of every culture. What every culture does is to engineer these in its own which is peculiar to their music. Even within each culture, these same raw materials are engineered into different types of music for different uses.

There is still another well versed description of folk music which had been widely accepted and it reads thus:

Folk music is the product of a musical tradition that has been evolved through the process of oral transmission. The factors that shape the tradition are

i. Continuity, which links the present with the past;

ii. Variation, which springs from the creative impulse of the individual or the group; and

iii. Selection by the community, which determines the form, or forms, in which the music survives. The term can be applied to music that has been evolved from rudimentary beginnings by a community uninfluenced by popular or art music and it can likewise be applied to music which has originated with an individual composer and has subsequently been absorbed into the unwritten living tradition of a community... for it is the re-fashioning and re-creation of the music by the community which gives it its folk character (in Karpeles, 1973:3).

Music is of course, a cultural expression and every culture decides for itself what is music or not (Merriam, 1964, Blacking, 1976). One social characteristic of folk music is that it is functional-integral with life and the rhythms of life. The anthropological works by Meek (1925) and Talbot (1926) show that Nigeria has at least 250 languages and dialects which define their various environments as ethnic groups.

Folk music springs from the real ground or depth of culture and can develop or grow through the years immitating, enlarging, shedding but always maintaining its original genre. In Nigeria and the Igbo area in particular most of the traditional or folk music are found in the rural areas as well as in such situations where the traditional culture operates.

\section{Functions of Music in Africa}

a. In a typical African society, music plays an important part in the lives of the people and one of the major characteristics of African music is that it is functional. The various stages of the life cycle of an individual and that of the society are all marked with music. For the life cycle of an individual viz birth, childhood, puberty, adolescence and death are marked in music. In the same vein the life-cycle of the society; the change in seasons, the beginning and end of agricultural activities, war and peace, joy and sorrow etc are all marked with music.

b. Birth: Music plays an important role in the life of a child. His birth is announced with singing and dancing and most importantly if the child is the first male or female of the family. The child's naming ceremony is also marked by singing and dancing. The women that had attended that naming ceremony can also be identified because of the appearance of patches of powder on their faces.

c. Initiation: The initiation ceremony that transforms manhood or womanhood into adulthood is marked with music. When a person changes his social status by marriage or taking of title, music is a means to achieve this transformation.

d. Death: After the death of an adult, the mortuary ceremonies differentiate the status of the individual and music is one of the symbols used to achieve this differentiation. Music that is used for the mortuary rites, the types of drums and flutes that are rolled during the funeral of a warrior is different from that of an elderly man (onye ichie). Music is stratified into hierarchies likewise the extensive nature of the funeral rites to reflect the social hierarchies occupied by individuals within the system.

e. Means of Communication: In the traditional African society and Nigeria in particular music announces the dawn and the closing of the day. Here the big village drum (called Ikoro) the flute or animal horn sounds its music saluting the rising sun and in the evening. During the day, activities such as laying of foundation of new buildings, farming ceremonies, marriages (Igba Nkwu, Ibu Nmaya Nwanyi) are graced with melodies or rhythms of music. Similarly each newborn moon heralds a new religious activity signified through the appropriate music to go with it of which the flute $(O j a)$ plays a vital role. The 
communication code linking the invisible world of deities and the visible world of men is music.

The fact that Africans depend on music as a means of communication within and outside this world has been misinterpreted by some observers as: the merry Africans and recently as lazy singing Africans (Ebighgbo, 2000). All these interpretations are born out of ignorance but the fact remains that the traditional African sees a link in the time past, the present and the future. This link is symbolized by sound of music.

f. Folk Tale/Literature: In African folk tale, the main oral literature of many societies, and in traditional myths, is man, spirits, animals, plants the elements, living and non-living things and various forces are brought to the same level of action and interaction through the performance of music.

g. Commerce and Industry: The involvement of music in all African social activities is quite striking. Its involvement in food production, distribution and consumption industry, mental and physical health, transport and communication, clothing and body adornment, settlement and housing are all mirrored in their music and dance.

Furthermore, African traditional music is the music of the farmer, the fisherman, the hunter, the craftsman, the trader and the palm wine tapper. All the above mentioned tradesmen and women perform music and dances as they engage in their different trades. They compose music and dance and finally transmit it from one generation to another through an elaborate process of socialization.

h. Cultural Heritage and Mark of Identity: Music is a cultural heritage and serves as a mark of identity. In other words it brings about group solidarity which is a significant instrument in the achievement of National Development. As a cultural heritage of a peoples way of life is shared through music no matter the producer, it is assumed not to be man's property. This is likened to the reference in the Holy Bible Psalm 137:1-4 which says; By the rivers of Babylon, there we sat down, yea, we wept, when we remembered Zion. We hanged our harps upon the willows in the midst thereof. For there they that carried us away captive required of us a song' and they that wasted us required of us mirth; saying sing us

one of the songs of Zion. How shall we sing the Lord's song in a strange land?
Actually many communities have built schools, canals, civic centres, etc through monies generated through their dancing musical groups.

i. For Tourism: African music is both an image maker and a source of economic venture and development. For example, the All Black African Festival of Arts and Culture (FESTAC 1977) held in Nigeria during the military regine of major General Yakubu Gowon attracted people from many countries thereby turning Nigeria into a tourist centre. It fetched Nigeria huge sums of money for development. Besides, it was during this period of musical exhibition that the FESTAC Village in Lagos was established and up till date had remained a commercial nerve centre.

\section{The Igbo Society}

The Igbo land is the home land of one of the dominant ethic groups in Nigeria occupying the forest region of the South-Eastern Nigeria with an overflow across the River to the fringes of the WestNiger Delta. The Igbo people are basically farmers, traders craftsmen whose social life flows with the rhyme of festival, ceremonies, rituals and work.

Some anthropologist trace the root of Igbo to the "Kwa" suffix for forest, so that according to one theory, Igbo means "people of the forest belt"? This forest environment has affected the nature of Igbo settlements which usually are scattered and small. The people in these settlements seems to be fiercely independent and regard themselves as citizens of a complete world which can interact with others only on mutually agreed principles. An Igbo settlement generally is a republic and in principle live an egalitarian life. (Okafor, 2005)

Igbo communities are in most cases made up of families and family groups which make up villages, towns and clans. Every community has a central place used for meetings, ceremonies, rituals or festivals. This place generally known as the village square provides the space of every community theatre (Basden, 1921). The Igbo has dialectical differences within the same group that speak the same language. The distinctiveness of the Igbo as a people within a broad linguistic group is known by the most dialects today, such as Wawa Igbo, Awka Igbo, Onitsha Igbo, Aro Igbo, Afikpo Igbo, Owerri Igbo, Bende Igbo, Rivers Igbo and West Niger Igbo.

\section{Music in Igbo life.}

Several types of music dominate the Igbo life which is basically rhythmic and danceable like other types of African music. Social music used for entertainment, 
didactic tales, narration of topical events, transmission of clan chronologies, social control and work music are some of the types available within the Igbo society. The Igbos looks for more than melody and rhythm in their songs and dances. They look for those things which express their collective experience and desired goals (Nnamani, 2009).

"To every Igbo, life has a melodic and rhythmic orientation, and again" no event happens that is not associated with music. The Igbos has an ardent personal felling for it" (Echezona, 1963:12). Also expressing his views on the importance of music among the Igbos, Okafor (1989) said the Igbos cannot do without music and one of the most important attributes of Igbo music is that it is not only to listen to, but also to learn from. Thus, music retains a permanent value and relevance in the Igbo society.

In a typical Igbo society, traditional education is a continuous and life-long event and music is not only an aid but an integral part of Igbo traditional system of education. Thus, music will indicate or express a ceremony and at the same time, be more than an external symbol and actually a sine qua non to its consummation. For example a ritual dance not only signifies that a ritual is taking place; but is necessary if the ritual is the be considered to have been performed or complete. Some Igbo ceremonial music requires select or closed audiences or performers. The ability to know how to relate to a specific ceremonial music or dance is an essential part of traditional education: Furthermore, skill in pre-requisite songs and dances is part of the social qualifications of an Igbo cultured man (Okafor, 1988). With respect to this assertion Herndon (1976) said;

What I may think does not in any way affect another group of people's ideas about their music. What they think of as music, and how they manipulate and develop those ideas, however, affects the form and substance of that music (pages 222-223)

\section{Music in Culture}

Culture is the sum total of a nation's customs, rituals, norms and values that regulate the people's way of life. A society is distinguished from another as a result of culture.

Music can as well claim to be the expression or art that is most accessible to human beings in any situation in their lives may be in times of crisis or calm, work and worship, play or war, recreation or reflection. Music is implicated in life and people go all out to use music to communicate, move, express emotions and ideas and to mobilize and rally people for solidarity. The national music of any people is a rallying point a marshalling point for expression of solidarity.
This takes place not only in the larger countries which have national anthems but also in the smaller ones, schools and communities. Schools have anthems; churches have anthems and likewise do age groups and occupational groups. These group are known by these music and dances and which they express their personality and identity and whenever the music typical of the group is sounded people rally round it expressing their solidarity. This is one reason why music is taken seriously in religious communities, social groups occupational groups, military and in national development.

\section{Role of Music in Cultural Development}

Folk or traditional music plays important parts in the cultural development of both the adult and younger generation of the society. The potentials of the children are developed from birth while the adolescents and adults are nurtured to full maturity through music and other aspects of culture. Okafor (2005), notes that "the Igbo child is a product of nature and nurture". This is seen in traditional Igbo music by the way the child is exposed to different musical activities he engages in at different stages of his growth and development.

i. Physical Development: Traditional music education involves physical activities where with psychomotor actions, the brain and other parts of the body are developed for physical fitness. This involves dancing, exercising and acrobatic shows of different forms.

ii. Intellectual Development: Music through folktales and songs help to develop the intellectual abilities or potential in children. Infact what the child sees or hears at this early period forms the foundation of his/her education to be utilized later in life. The child's first lessons in music are thus given by its mother before the father, siblings, peers and other people within the environment. Through the mother, the child learns to develop its sense of pitch

iii. Social Development: Music is a means of socialization for the child within the society. From childhood, the child gets acquainted with the members of the society. The musical activities involved in children's games are designed to generate and foster the spirit of espirit decorps which is a vital element in Igbo societal life in which there is competition, socialization with individuals and other members of the group.

iv. Vocational Training: Through drumming, dancing and singing, good singers, dancers and drummers 
are developed. This type of training is not a formal type in which they are organized in a formally recognized institution. The training her is by rote, practice and immitation. Supporting this Okafor (1980:129) said;

the music training is by rote, since that aspect of Nigerian culture is still an oral tradition. The technique of rote teaching is supplemented by imitation, repetition and slow absorption.

\section{Cultural Policy}

Cultural Policy is the area of public policy-making that governs activities related to the arts and culture. The idea of cultural policy was first created at UNESCO in the 1960s. Generally this involves fostering processes, legal clarifications and institutions that promote cultural diversity and accessibility, as well as enhancing and promulgating the artistic, ethnic, sociolinguistic literary and other expressions of all people, especially those of the indigenous representative of cultural heritage.

At the international level it include hosting of corporate-sponsored art exhibitions, community dance classes, establishment of ministries of culture and National Endowment for the Humanities and the Arts. Similar significant organizations that exist in the United Kingdom and other developed countries include the Department for Culture, Media and Sports and Arts council. Throughout the $20^{\text {th }}$ century period, much of the activities that are now regarded as cultural policy were governed under the title of "arts policy".

Nevertheless according to Mulcahy, (2006)

Cultural policy encompasses a much broader array of activities than were addressed under arts policy. Whereas arts policy was effectively limited to addressing aesthetic concerns, the significance of the transformation to cultural policy can be observed in its demonstrable emphases on cultural identity, valorization of indigineity and analyses of historical dynamics such as hegemony and colonialism.

A cultural policy is necessarily made up of a broad array of activities and typically involves public support for the following.

* Heritage, battlefield and historic preservation sites.

* Zoos, botanical gardens, arboretums, aquariums, parks
* Libraries and Museums (fine arts, scientific historical)

* Visual arts (film, painting, sculpture, pottery, architecture)

* Performing arts (symphonic, chamber and choral music'; jazz, hip-hop and folk music; ballet, ballroom and modern dance; opera and musical theatre circus performances, rodeos and marching bands.

* Public humanities programs (public broadcasting, creative writing, poetry)

Since culture is something of public value and something that is "good for you" governments have pursued programmes to promote its greater accessibility. Consequently various types had emerged viz cultural democracy or democratization of culture cultural, capital, cultural patronage etc.

\section{Scope of cultural Policy}

At the international level UNESCO is in charge of cultural policy. The contact information for the ministries of culture and national arts councils in 160 countries is available from the international federation of Arts councils and culture Agencies (IFACCA).

\section{International Cultural policy.}

Cultural cooperation of Nigeria and others are carried on the basis of the signed agreements, either bilateral or multilateral. The coordinating agency for cultural cooperation is the Federal Department of culture.

Regional African Cooperation is mostly based on the common developmental experience and some similar characteristics of African cultures. It is motivated by the need to work on the emancipation of African cultures. The Black African arts and civilizations tried to establish mutual links and exchange, which is not very easy as the authentic values and types of communication do not normally bring them closely together. Pan-African festivals offer an occasion for over-all presentation of arts and crafts and the Nigerian government had hosted such manifestation as that of FESTAC 1977. (FGN, 1982)

Cooperation with the western world is mostly based on the presentation of Nigerian arts and crafts or Nigerian music to the western audiences and on the transfer of knowledge of cultural institutions and activities from the west. Cooperation with the United Nations and particularly UNESCO is here of special concern. Apart from the support for festivals, exhibitions etc UNESCO pays particular attention to relevant cultural issues such as copyright information management and enforcement, collection, analysis and documentation of the oral traditions, 
restoration and conservation of national monuments, creative writing education training in Specialized National Institute for cultural orientation etc. It is also through this organization that the Nigerian cultural institutions or associations joined Specialized international associations and organizations. (FGN 1982)

\section{Cultural Policy in Nigeria}

Simply defined;

A cultural policy is a body of operational principles and administrative and budgetary practices which form the basis of cultural action or non-action by the state. Thus a cultural policy would facilitate or impede the management rational selection and determination of cultural programmes with emphasis on specific areas of government participation (Okafor, 2004: 29).

A National cultural policy is generally regarded as an instrument of promotion of national identity and Nigerian unity as well as of communication and cooperation among different Nigerian or African cultures, while the federal states' cultural polices stand for the affirmation and development of a particular ethnic cultures.

\section{Agencies Involved in Promotion of Cultural Policy}

The National council for Arts and Culture encourages and develops all aspects of Nigerian cultures and interacts with the private and public organizations in these directions. Other federal bodies partly involved in cultural life and policies are Ministry of Information and Ministry of Education. Also other cultural sectors involved at the Federal level include; National Commission for Museums and Monuments, National Library of Nigeria, Centre for Black and African Arts and Civilization, National Gallery of Modern Art, Federal Radio Corporation of Nigeria, Nigeria Television Authority, Film Corporation of Nigeria. The various State Art councils are also involved at the state levels.

\section{Objectives of Nigerian Cultural Policy}

The cultural policy for Nigeria (1988) provides for the following objectives: The policy shall serve to mobilize and motivate the people by disseminating and propagating ideas which promote national pride, solidarity and consciousness.

The policy shall serve to evolve from our plurality, a national culture, the stamp of which will be reflected in African and world affairs.

The policy shall promote an education system that motivates and stimulates creativity and draws largely on our tradition and values, namely, respect for humanity and human dignity, for legitimate authority and dignity of labour, and respect for positive Nigerian model and religious values.

The policy shall promote creativity in the fields of arts science and technology; ensure the continuity of traditional skills and sports and their progressive updating to serve modern development needs as our contribution to world growth of culture and ideas.

The policy shall establish a code of behavior compatible with our tradition of humanism and disciplined moral society.

The policy shall sustain environmental and social conditions which enhance the quality of life, produce responsible citizenship and an ordered society.

The policy shall seek to enhance the efficient management of national resources through the transformation of the indigenous technology, design resources and skills.

The policy shall enhance national self-reliance and self-sufficiency, and reflect our cultural heritage and national aspiration in the process of industrialization. (P.6.).

The implementation, promotion and development of these policies is the exclusive responsibility of states although the Federal Government Finances them and offers administrative support for culture. State or provincial authorities have also established State Art Councils backed by law. These art councils have the responsibility to develop, administer and promote state cultural policies.

\section{Theoretical framework}

The Traditional Igbo Society was not a literate one but we had our culture, traditions and music before the coming of the Europeans. In the olden days Igbo people did not derive entertainment from books, rather they developed and derived joy from imaginations through oral narratives including traditional/folk music. Specifically according to Emenyonu (1978) he said; Igbo oral tradition or folklore (oral performance) is the foundation of the Traditional Igbo music. Igbo oral performance include such as folksongs, folktales, riddles, proverbs, prayer including incantations, histories, legends, myths, drama, oratory (forensic and others) and festivals from these grow the roots of Igbo life, its culture and its worldview...Traditional Igbo music reflects the 
inner characteristics of our culture, beliefs,

philosophies and world view. (2)

The young generation of the Igbo society learn to appreciate the basic ideas of life, their people's fundamental values, their system of personal relationship and their sense of humour through folksongs. Through folksongs, emotion and feelings are expressed or elevate after the days hard work in the evenings.

Thus, it is a veritable instrument for education which invariably influences the younger generation for positive change in life and fit into the society. Hence Okafor (1989) observes that women are the first music teachers because they teach children by singing lullaby and folksongs to pacify and they learn by intuition.

To Egonu (2009), music represents anything that is sung, chanted, danced or chorused to project the aesthetics of the human mind. It demands one's cognitive ability, elevates the spirit into a state of ecstatic/nostalgic consciousness leading to a feeling of joy, anger, pity and kindness. Music brings healing to the soul, makes one sober to reflect on the issues of life. This is one of the art forms through which young indigenes are initiated into the society, prepared for adulthood, social responsibility, job orientation, political participation in leadership roles as well as for moral values.

\section{RESEARCH METHODOLOGY}

Music is ubiquitous in human society. It permeates all aspects of human life (social, economic, cultural, political, historical, religious etc) and no society exists without one form of music or the other. In Igbo society (southeastern part of Nigeria), different brands of music such as egwu nwa (maternity songs) egwu echichi (installation songs), egwu agha (war songs), egwu onwa (moonlight play songs), egwu ogene (music played using metal gong), egwu une (music played with bowed instrument) etc exist for different ceremonies and festivals. These include childbirth and naming ceremonies, funeral, masquerade, war, new yam, coronations/initiations among others.

Also the poetic justice found in folksongs serves the purpose to reform and instruct the society. Music arouses feelings and the intellect in Igbo culture. Some folktales are structured in a way that they are chanted with imagery messages emerging only with deeper reflections. To these Bascom (1965) says "they play very vital roles in the education of young ones because they serve as vessels used in the transmission of cultural values, customs and moral codes, social and religious institutions". Traditional
Igbo folksongs are adopted even today as a way of expressing opinions on important contemporary is sues.

The data for this work comes from five different folksongs of Igbo origin. Each song is purposively selected from the areas of Egwu nwa (maternity songs), Egwu echichi (installation songs), Egwu akwamozu (funeral song), Egwu agha (war song) and Egwu onwa (moon light song). The Iyrics which are in Igbo language are translated into English. The analysis of the themes in the music is done through content analys is (surface and deep structure).

1. Analysis: A Na-azu Nwa N'ahia - If a child were to be purchased

\section{Igbo English}

A na-azu nwa n'ahia, If a child were to be purchased from the market

Ona-adi n'obi ndi ogalanya - It would have been found in the homes of the rich

Ma Chineke e mee la ogo -But, God is so benevolent Onye o mayina ya rie - That He gives it freely to anyone.

For the Igbo, there is great joy and happiness in the birth of a child in the home especially if he is a male child. There is not only joy and thanks giving but also the appreciation that a genealogy is being expanded and that certain hopes can be fulfilled. They have the philosophical belief that the family lineage will continue unabated. Furthermore, the expression o na-adi n'obi ndi ogalanya (it would have been found in the homes of the rich, shows that the rich have the desire that only their families will have access to the good things of life. Nevertheless, it is not so because God is so benevolent that He distributes children freely to the rich and to the poor. There is a strong belief in Igbo society that children are free gifts and therefore when a child arrives in the home, there is usually dancing, singing, happiness and merriment.

Moral Development: It is through these songs that the Igbo child and in fact every African child is nurtured into the tenets of the society. Traditional Igbo music is a steering force to the proper understanding of African culture and it then becomes obvious that adequate attention is given to it to ensure continuity. Therefore a child who is well tutored in the cultural activities of his community will grow up to protect and foster it. Reaffirming this Agu (1990) then said; since all Igbo music including lullabies are affected by the constitution of the societies as well as governed by conventions, children are led to absorb these conventions through music right from the start... through this practice, children become fully acculturated into the music system by the time they grow up (p.50).

2. Analysis: Egwu Echichi Coronation song 
Igbo English

Obi lele ah-The king is coming

Obi lele ah-The king is coming

Oro ro ma ya ah -The handsome king

Oro ro ma ya ah -The handsome king

African gods are music loving and manifest themselves in musical situations in which ritual activities in festivals and coronations are performed. It is through their human medium that the gods descent to participate in the ceremony. Some special folk songs are used to worship the ancestral gods and sustain their presence. Of a truth, the requests of the worshippers would only be addressed by the gods if they were sufficiently appeased through their folk songs. According to Ehiwario (2005); the gods and spirits demand an atmosphere physically elevated and ionized above human frequencies to become frenzied with men. Folk music is the prime agency through which the bond between the living and the gods and the ancestors is articulated reaffirmed and renewed during and after satisfactory offerings and sacrifices. Remove the functional presence of folk music from the organization of observation festival and what would be left of the conduct of the theme to make a festival? (p 101). It is music that brings the Natural Rulers (Eze; Onyeisi or Onyeze) out of the purification house and music takes or leads himback to the palace and with music he goes to the shrine where he worships his gods. This is typical of the example quoted above.

\section{Analysis: Fgwu Akwamuozu Funeral Song Igbo English}

Ugo bere n'oji efeliele - Eagle on the iroko has disappeared O dikwa onye iwe ji? - Is anyone annoyed?

Ugo bere n'oji efeliele o - Eagle on the iroko has disappeared

O dikwa onye iwe jie? - Is anyone annoyed?

Dede lee owe o - Elder brother go well

O dikwa onye iwe ji?.. - Is anyone annoyed?

Onye umunne ya n'adighi vuru nnie...His brothers are still there

Ahe gala foro ya (2ice) - We will still remain (2ice)

Dede lee, ehee - Elder brother see us

Ahe gala foro ya - We will still remain

Onye umunne ya nadighi vuru nnie - His brothers are still there

Ahe gala foro ya... - We will still remain

Funeral music of special rites are accorded to old people in Igbo traditional communities. Examples of such music are "Ukom" and "Esse" from Ngwa and Mbaise communities respectively. They are used to express their social values, societal bonds, honour and the level of their achievements in the society. The Ahiajoku Lecture (Onugotu) Colloquim (1991) explained that as, "Abu Akwamaozu are funeral rites of any significance in Igbo land is laden with meaning and expression of social values. The music and drama, plain nut pouring of grief, the ugly and beautiful may impress or perplex (p. 21,22).

\section{Analysis: Egwu Agha War: Song}

Igbo English

Nzogbu, nzogbu - Trample, Trample

Enyi mba Enyi - Elephant city elephant

Nzogbu, Enyi mba - Trample, Elephant city

Zogbuo Nwoke enyi mba - Trample man elephant city

Zogbuo Nwanyi enyi mba - Trample woman elephant

Nzogbu, nzogbu enyi mba Trample, trample elephant city.

The use of "Enyi mba enyi" (Elephant city) is used

here as a motivating word that will spur the soldiers to be brave during warfare. It is noteworthy that in Igbo society no other animal is bigger and stronger than the elephant. Therefore when such songs are rendered the soldiers will be motivated to fight gallantly. Igbo elders usually take the title "Anu ka Enyi" meaning No animal is greater than Elephant.

5. Analysis: Udala Nwa-ogbeye- The Orphan's Apple Tree

Udala nwa-ogbeye - Orphan's apple tree

Sobe, sobe, sobe - Grow, grow, grow

Sobelu nwa-ogbeye - Grow for the orphan

Nwanyi jebe afia - The woman goes to the market

Gote udala n'afia - Buys apple fruits from the market

Nyesia umu ya - Shares to her children only

Ma ya enye nwa-ogbeye - And does not give the orphan

Nwa-ogbeye enwe nne - Orphan without mother

Ma ya enwero nna - And orphan without father

The African star apple known as "udala" among the Igbo is a tree of life in Igbo culture. It grows in many homesteads but in a special sense is a common property. In some part of Igbo land this tree forms the focal point or venue for a fertility rite. Agukoronye (2000) has this to say about the udala; it is a popular fruit tree which for the Igbo symbolizes fertility and the spirit of children... if serval children go to an udala stand and only one of them picks up a fruit, he never eats it alone. He shares it with his mates. This is the spirit of sharing, brotherly love and the innocence of children which the udala symbolizes. In some communities, some rites are performed before the udala ripens. Children clean the bush around the udala tree and till the ground to make it soft for the fruits, to fall on without breaking. On a specified festive day, they bring 
food items from their homes and collectively cook them under the udala tree. Each child scoops out some food and casts it under the udala tree as a kind of libation. They then eat the rest of the food together singing, rejoicing and looking up to the udala to reward them (p.10)

Everywhere in Igbo land there are folktales and songs about the tree. It is a tree of hope, petition as was typified in the song stated above. It puts a glow of hope in the eyes of Igbo children from generation to generation.

\section{CONCLUSION}

Traditional Igbo folklore is the basis of traditional Igbo music. It includes folksongs, folktales, riddles, proverbs, incantations legends, myths, drama etc. These had been shown in the examples shown in this paper in the types of "Egwu nwa" (Maternity songs), Egwu echichi (coronation songs), Egwu akwanuozu (funeral songs) Egwu agha (war songs) and Egwu Onwa (folk songs.)

It is through Igbo traditional music that the young ones learn to appreciate the basic ideas of life their people's fundamental values, their system of personal relationships and their sense of humour.

\section{References}

[1] Agu, D.C.C (1990). "The primacy of music in Igbo, Traditional Religion" In Ekpunobi, E. and Ezeaku (ed) socio-philosophical Perspective of African Traditional Religion. Enugu: New Age Publishers.

[2] Agukoronye, O.C. (2000). "Landscaping and Land Care in Traditional Igbo Society". An unpublished paper.

[3] Ahiajoku Lecture (onugotu) (1991). Colloquium p.21

[4] Basden, G.T (1921). Among the Ibos of Nigeria. London: Seely services and Co.Ltd (Reprinted 1966, London: Frank Cass Co.Ltd

[5] Basden, G. T. (1966). Niger Ibos. London: Frank Cass \& Co.Ltd. (First published 1938, London: Seely services \& Co.Ltd).

[6] Bascom, W. (1965). "Folklore and Literature" in Lystad, R;(ed). The African World, New York.

[7] Blacking, J. (1976). How Musical is Man? London: Faber \& Faber Ltd.

[8] Cappallettei, V. (1972). Cultural Policy in Italy. UNESCO Publication

[9] Ebighgbo, C.N (2000). African Music in Onwuejeogwu et al: Civilization Origin, Growth and Development. U.T.O Publications, Lagos
[10] Echezona, W.W.C (1963). Ibo Musical Instruments in Ibo Culture. Ann Arbor: Michigan University Microfilms.

[11] Egonu, N.G (2009). "The Role of Traditional Igbo Music in Education and National Development" In Alvan Journal of Music and Humanities Vol . No

3

[12] Ehiwario, M.O (2005) "Music in Nigerian Festival" In Nigerian Musicology Journal Vol 1. No 1 A Journal of the Assocation of Nigerian Musicologists (ANM)

[13] Emenyonu, E.N (1978). Ideas and Challenges in Nigeria Education. Enugu: New Generation Books.

[14] Encyclopedia Americana International (1995) Grolier Incorporated. New York

[15] Federal Republic of Nigeria (1988). Cultural Policy for Nigeria. Federal Government Press.

[16] Festival of Arts and Culture (FESTAC) (1977) Festival Journal, Federal Government of Nigeria (1982).

[17] Glennon, J.(1980). Understanding Music. London: Macmillian Publishers

[18] Holy Bible (2002) Psalms 137:1-4. King James Version; Jet Move Publication

[19] Herndon, M. (1976). Reply to Kolinski: Tarus Omnicidia. Ethnomusicology, $\mathrm{xx} \quad$ (2), $217-231$

[20] Hornby, A. S. (2000). Oxford Advanced Learners' Dictionary of Current English. New York: Oxford University Press

[21] Kapeles, V. (1971). Cultural Policy in Italy. UNESCO Publication

[22] Meek, C. K (1925). The Modern Tribes of Nigeria. Vols 1 \& 2 London: O.U.P

[23] Merriam, A.P. (1964). The Anthropology of Music. Evanston: North Western University Press

[24] Mulcahy, K.V. (2006). What is Cultural Policy? From Wikipedia, the free encyclopedia.

[25] Nnamani, S.N. (2009). "Globalization of the Igbo (Nigeria) Music-chorus Practice" in Interlink: A Journal of Research in Music Vol. 4. Abimac Publishers

[26] Okafor, R.C. (1980). Igbo Minstrels. Ph.D Thesis, The Queen's University of Belfast.

[27] Okafor, R.C. (1988). "Technology and its Social Effects on Music in Nigeria Today". The Humanities in Contemporary Nigerian Education In J.C. Nnadi(ed) Eha-amufu College of Education 147 - 154 
[28] Okafor, R.C. (1989a). "Popular Music education in

Nigeria" International Journal of Music

Education. 14:3 - 13

[29] Okafor, R.C. and Ng'andu, J. (2003). "Musical Storytelling". In Musical Art in African:

Theory, Practice and Education. Eds Anri Herbst, Meki Nzewi and Kofi Agawu. University of South Africa: Unita Press, 179 - 194

[30] Okafor, R.C. (2004a). "Types of Music in Nigeria". In R.C. Okafor \& L.N. Emeka, (Eds), Nigerian peoples and Culture, $4^{\text {th }}$ edition (pp147-174). Enugu: New Generation Books

[31] Okafor, R.C. (2005). Music in a Technological University. $14^{\text {th }}$ Inaugural Lecture Enugu, New Generation Books.

[32] Okpala, A.A. and Anuforom, U. (1988). Fundamentals of Music. Owerri: Colon Concept Ltd.

[33] Okpala, A.A. (1996). "Perception: An Important Factor in using music for Effective Communication". Journal of Social Studies Vol. 1(1) 107

[34] Scholes, P.A (1970). The Oxford Companion to Music (10 ${ }^{\text {th }}$ Edition). London: O.U.P.

[35] Talbot, P.A. (1976). The peoples of Southern Nigeria, 4 Vols London: Humphrey Milford. 